Article

\title{
Eicosapentaenoic Acid from Porphyridium Cruentum: Increasing Growth and Productivity of Microalgae for Pharmaceutical Products
}

\author{
Maryam Asgharpour, Brigitte Rodgers and Jamie A. Hestekin * \\ Ralph E. Martin Department of Chemical Engineering, University of Arkansas, Fayetteville, \\ AR 72701, USA; E-Mails: masgharp@uark.edu (M.A.); bmr002@uark.edu (B.R.) \\ * Author to whom correspondence should be addressed; E-Mail: jhesteki@uark.edu; \\ Tel.: +1-479-575-3492; Fax: +1-479-575-7926.
}

Academic Editor: Thomas E. Amidon

Received: 16 June 2015 / Accepted: 15 September 2015 / Published: 22 September 2015

\begin{abstract}
An alternative source of eicosapentaenoic acid (EPA) or omega-3 could be microalgae lipids instead of fish oils. However, EPA and lipid contents extracted from microalgae vary at different growth conditions. Therefore, it is of paramount importance to optimize the growth conditions of microalgae to maximize EPA production. In this paper, the effects of temperature $\left(16{ }^{\circ} \mathrm{C}\right.$ and $\left.20{ }^{\circ} \mathrm{C}\right)$, light intensity $\left(140 \mu \mathrm{E} \mathrm{m}^{-2} \mathrm{~s}^{-1}\right.$ and $\left.180 \mu \mathrm{E} \mathrm{m}^{-2} \mathrm{~s}^{-1}\right)$ and nitrate level $(0.075,0.3,0.5$, and $0.7 \mathrm{~g} / \mathrm{L})$ on the cell growth, lipid productivity, and omega-6/omega-3 ratio of Porphyridium cruentum, one of the most promising oil-rich species of microalgae, are investigated. The ratio of the fatty acids with omega-6 and omega-3 groups at various growth conditions were compared, since an appropriate proportion of $\omega-6$ (arachidonic acid (ARA)) to $\omega-3$ (EPA) is vital for healthy nutrition. Lower EPA production and consequently a higher ARA/EPA ratio occurred when $5 \% \mathrm{CO}_{2}$ /air was utilized as $\mathrm{CO}_{2}$ supplementation compared to pure $\mathrm{CO}_{2}$. The highest EPA $\left(13.08 \%(\mathrm{w} / \mathrm{w})\right.$ of total fatty acids) and biomass productivity $\left(143 \mathrm{mg} \mathrm{L}^{-1} \mathrm{day}^{-1}\right)$ was achieved at $140 \mu \mathrm{E} \mathrm{m}^{-2} \mathrm{~s}^{-1}, 20{ }^{\circ} \mathrm{C}$, and $0.3 \mathrm{~g} / \mathrm{L}$ nitrate, while lipid content was the lowest $(0.5 \% \mathrm{w} / \mathrm{w})$ at this condition. The optimal condition with minimum ARA/EPA ratio (2.5) was identified at $20{ }^{\circ} \mathrm{C}, 140 \mu \mathrm{E} \mathrm{m}^{-2} \mathrm{~s}^{-1}$, and $0.5 \mathrm{~g} / \mathrm{L}$ nitrate concentration.
\end{abstract}

Keywords: eicosapentaenoic acid (EPA); fatty acids; lipids; microalgae; photo bioreactor; Porphyridium cruentum 


\section{Introduction}

The natural products of microalgae are becoming increasingly important within the scientific community for their different applications, such as in pharmaceuticals [1] and biofuel production [2]. The advantages of microalgae are significant and include: more oil yield per area of microalgae compared to the foremost oilseed crops, less water required for growth, the possibility of cultivation in seawater or non-arable lands [3], production of valuable co-products such as proteins and residual biomass of oil extraction [1], and pharmaceutical products such as omega-3 fatty acids ( $\omega-3)$. It has also been indicated that long-chain N-3 polyunsaturated fatty acids, such as eicosapentaenoic acid (EPA, C20:5 n-3) and docosahexaenoic acid (DHA, C22:6 n-3), play important roles in the treatment of many diseases such as cancer, atherosclerosis, rheumatoid arthritis, Alzheimer's, and psoriasis [4,5].

EPA or $\omega-3$ is a polyunsaturated fatty acid (PUFA) containing 20 carbons in its chain and five cis double bonds. One of the major nutritional requirements in our diet, adequate omega-3 fatty acid intake improves infant cognitive development and visual acuity [6]. Recent medical studies recommend that both preterm and at term infants need to receive an appropriate ratio of $\omega-3 / \omega-6$. Thus, it is becoming common practice in many countries to include them in baby formula [7]. EPA plays a main role in altering membrane fluidity, as the precursor to different biologically active regulators such as hormones, and in reducing plasma triacylglycerol and cholesterol levels [8]. Also, it has been demonstrated that EPA can reduce the risk of some diseases such as diabetes [9], brain disorders [10], arteriosclerosis, coronary heart disease, inflammation, and several carcinomas [11]. Unbalanced intake of omega- 6 to omega-3, mainly the insufficient uptake of omega-3, results in increased cardiovascular diseases, risk of cardiac death, and mental illnesses. A diet with a ratio of 1:1 is ideal, while ratios higher than 10:1 are not recommended [7].

Mammals are unable to synthesize EPA due to the absence of the essential enzymes that place a double bond at the $\omega-3$ position [12]. Currently, the richest source of EPA (up to $15 \%$ of total fatty acids) is fish oils [13,14]. However, fish oil drawbacks include peculiar taste, contamination, odor, availability, quality, oil stability, and high costs of purification and extraction [5]. Therefore, the search for an alternative source has been encouraged [8]. A promising source of EPA and DHA is microalgae, which has become increasingly attractive for the commercial production of these fatty acids [5].

The first parameter to successful algal biotechnology is selecting the right microalgae species with appropriate characteristics, for example, fatty acid content and biomass productivity [15]. Therefore, primary strain selection is the most important factor in achieving maximal desired fatty acid compositions and yields. Several studies have screened different microalgal strains to identify those with high EPA yields [5]. Microalgae such as Chlorella minutissima [16], Porphyridium cruentum [17], Ocharomonas danica [18], Phaeodactylum tricornutum [19], and the freshwater alga Monodus subterraneus [20] were suggested as potential sources. Porphyridium cruentum has demonstrated high amounts of long-chain polyunsaturated fatty acids (PUFA) and EPA. In addition, the individual production of EPA without docosahexaenoic acid (DHA) has been considered because of the different pharmacological and nutritional importance. Therefore, it is important to select an alga strain with less DHA than EPA potential. P. cruentum is one of the best strains for EPA production, with yields exceeding $19.7 \mathrm{mg} / \mathrm{L}$ of EPA, without any production of DHA [5]. 
The contents of EPA and other fatty acids of microalgae can be changed under different environmental conditions, including light intensity, temperature, and nutrient composition [21]. Production of arachidonic acid (ARA, C20:4 n-6) during EPA production is detrimental because high concentrations of ARA can reduce EPA production and make recovery difficult $[19,22]$. Therefore, it is critical to have minimum ARA and maximum EPA, which can be controlled by growth condition optimization [13,17,23]. Total fatty acid and EPA contents for unicellular algae have been reported to decline with increasing temperature [24]. However, it has been shown that the lipid contents of $P$. tricornutum cells increase at higher temperature [20]. Other research has shown that the optimum temperature for optimal yields of EPA from P. cruentum should not exceed $25^{\circ} \mathrm{C}$ with a temperature of $30{ }^{\circ} \mathrm{C}$ resulting in a low concentration of EPA and high concentrations of ARA and other fatty acids [25].

Phototropic algae absorbs sunlight, thus artificial lighting is a critical factor in the commercial production of algae [26]. Low light intensity has been reported to increase accumulation and production of PUFAs of some microalgae cells such as Cyclotella menaghiniana, Nitzschia closterium, and Euglena gracilis [27-29]. However, the light intensity effect was reversed for the red alga $P$. cruentum [30]. It has been reported that light intensities lower than $30 \mathrm{~W} / \mathrm{m}^{2}$ inhibited the growth rate of Botryococcus braunii, while photo-inhibition and lower lipid amounts occurred at light intensities above $100 \mathrm{~W} / \mathrm{m}^{2}$. This occurs due to the low biomass and fewer hydrocarbons [31].

Another main factor affecting biomass and lipid productivity is culture medium composition. Nitrogen deprivation usually inhibits biomass growth. However, lipid-synthesizing enzymes are less susceptible to disorganization than carbohydrate-synthesizing enzymes in a nitrogen-limited situation, thus the lipid count increases. Subsequently, most of the carbon will be bound in the lipids [32]. Therefore, there should be a lipid productivity peak related to nitrogen concentrations at a certain nitrogen source. Miyamoto illustrated that lipid content from Nannochlolis decreased about $22 \%$ with increasing nitrate concentration from $0.9 \mathrm{mMol} / \mathrm{L}$ to $9.9 \mathrm{mMol} / \mathrm{L}$, while lipid yield as well as biomass productivity increased [33]. Several attempts have been carried out to establish the nutritional requirements of $P$. cruentum and to optimize the media formulation. Roessler [34] studied the nitrogen starvation effects on $P$. cruentum growth in 1990. They found that a lack of nitrogen in the culture medium can lead to the accumulation of lipids such as triacylglycerol (TAG) in microalgae cells. Cohen [35] illustrated that starvation generally resulted in a sharp reduction of content and proportion of PUFAs and also leads to the accumulation of saturated and monounsaturated fatty acids in algae cells in 1986. Cohen [17] also showed in 1990 that nitrogen starvation in P. cruentum caused increased amounts of TAG and ARA and consequently increased the ARA/EPA ratio.

The purpose of this project was to determine the optimal growth conditions for Porphyridium cruentum in order to achieve maximum fatty acid content, biomass content, and EPA concentration over other fatty acids, particularly ARA. The parameters investigated were temperature, light intensity, and nitrate concentration as well as $\mathrm{CO}_{2}$ supplementation. The desired outcome was to optimize the maximum productivity of EPA rather than other fatty acid content. A high content of EPA decreases the cost of extraction and purification and also increases the process yield coefficient [35]. 


\section{Experimental}

\subsection{Strains and Growth Conditions}

The marine microalgae Porphyridium cruentum, CCMP1328 isolated by the Provasoli-Guillard National Center for Marine Algae and Microbiota (NCMA, East Boothbay, ME, USA), was used. The cells were red and spherical with a length of 5-8 $\mu \mathrm{m}$. $P$. cruentum cultures were maintained in a modified L1 medium containing $\mathrm{NaNO}_{3}, \mathrm{NaH}_{2} \mathrm{PO}_{4} \cdot \mathrm{H}_{2} \mathrm{O}, \mathrm{Na}_{2} \mathrm{EDTA} .2 \mathrm{H}_{2} \mathrm{O}, \mathrm{FeCl}_{3} .6 \mathrm{H}_{2} \mathrm{O}, \mathrm{MnCl}_{2} .4 \mathrm{H}_{2} \mathrm{O}$, $\mathrm{ZnSO}_{4} \cdot 7 \mathrm{H}_{2} \mathrm{O}, \mathrm{CoCl}_{2} \cdot 6 \mathrm{H}_{2} \mathrm{O}, \mathrm{CuSO}_{4} \cdot 5 \mathrm{H}_{2} \mathrm{O}, \mathrm{Na}_{2} \mathrm{MoO}_{4} \cdot 2 \mathrm{H}_{2} \mathrm{O}, \mathrm{H}_{2} \mathrm{SeO}_{3}, \mathrm{NiSO}_{4} \cdot 6 \mathrm{H}_{2} \mathrm{O}, \mathrm{Na}_{3} \mathrm{VO}_{4}, \mathrm{~K}_{2} \mathrm{CrO}_{4}$, Thiamine-HCl (Vit. B1), Biotin (Vit. H), Cyanocobalamin (Vit. B12), and filtered seawater [36]. The media were modified by omitting $\mathrm{Si}\left(\mathrm{Na}_{2} \mathrm{SiO}_{3} \cdot 9 \mathrm{H}_{2} \mathrm{O}\right)$ from the original recipe. The medium was sterilized by autoclaving at $127^{\circ} \mathrm{C}$ for $30 \mathrm{~min}$.

P. cruentum was pre-cultured at $22{ }^{\circ} \mathrm{C}$ with natural illumination in a $500-\mathrm{mL}$ glass bottle containing $250 \mathrm{~mL}$ of medium. Afterwards, pre-cultured algae in the early exponential growth phase were inoculated at fixed cell numbers of around 5000 cells per $\mathrm{mL}$. Growth experiments were carried out axenically for approximately 30 days at two different temperatures $\left(20{ }^{\circ} \mathrm{C}\right.$ and $\left.16{ }^{\circ} \mathrm{C}\right)$ and illuminations (140 $\mu \mathrm{E} \mathrm{m}^{-2} \mathrm{~s}^{-1}$ and $180 \mu \mathrm{E} \mathrm{m}^{-2} \mathrm{~s}^{-1}$ ) for $13 / 11$ hours light/dark cycle. In addition, after optimizing light and temperature, four nitrate concentrations in the growth media including 0.075 (original recipe of L1-medium), $0.3,0.5$, and $0.7 \mathrm{gNaNO}_{3} / \mathrm{L}$ media were investigated in the best light intensity and temperature to see the effect of nitrogen levels. $\mathrm{pH}$ values were monitored daily during the experiments and the required $\mathrm{pH}$ was achieved by bubbling (approximately $5 \mathrm{psi}$ ) pure $\mathrm{CO}_{2}$ through a small hole at the bottom of the column. $\mathrm{CO}_{2}$ was bubbled periodically every couple of days for several seconds to reach the targeted $\mathrm{pH}$. In addition, one extra experiment was performed with a ratio of 5\% $\mathrm{CO}_{2}$ in the air to adjust the $\mathrm{pH}$ to investigate the effect of air in growth and lipid composition.

The algal cells were harvested in their stationary growth phase. Harvesting was performed by centrifugation at $5000 \mathrm{rpm}$ for $15 \mathrm{~min}$. The harvested biomass cake with about $80 \%$ moisture was washed with distillated water to remove non-biological material such as mineral salt precipitates. The pellets were lyophilized and then grounded to powder prior to fatty acid extraction. Figure 1 depicts the experimental bioreactor used for this research. The photo bioreactor (ePBR v1.1 was purchased from Phenometrics (Phenometrics, Inc. Alliance Drive, Lansing, MI, USA) and the experimental parameters (such as temperature and light intensity) were controlled simultaneously by a single computer running Algal Command, Phenometrics' software.

Cell numbers were counted using a microscope with a bright-light hemacytometer. Data were statistically analyzed to obtain the standard deviation. Calculations of growth rates $(\mu)$ were done using Equation (1):

$$
\mu=\frac{\ln \left(N_{t}\right)-\ln \left(N_{0}\right)}{t-t_{0}}
$$

where $N_{t}$ and $N_{0}$ are the cell density at time $t$ and $t_{0}$, respectively [23]. Moreover, the biomass productivity was presented by Equation (2):

$$
\text { Biomass productivity }(\mathrm{mg} / \text { Lday })=\frac{\text { Dried microalgae biomass }(\mathrm{mg})}{\text { Culture time }(\text { days }) \times \text { working volume }(\mathrm{L})}
$$




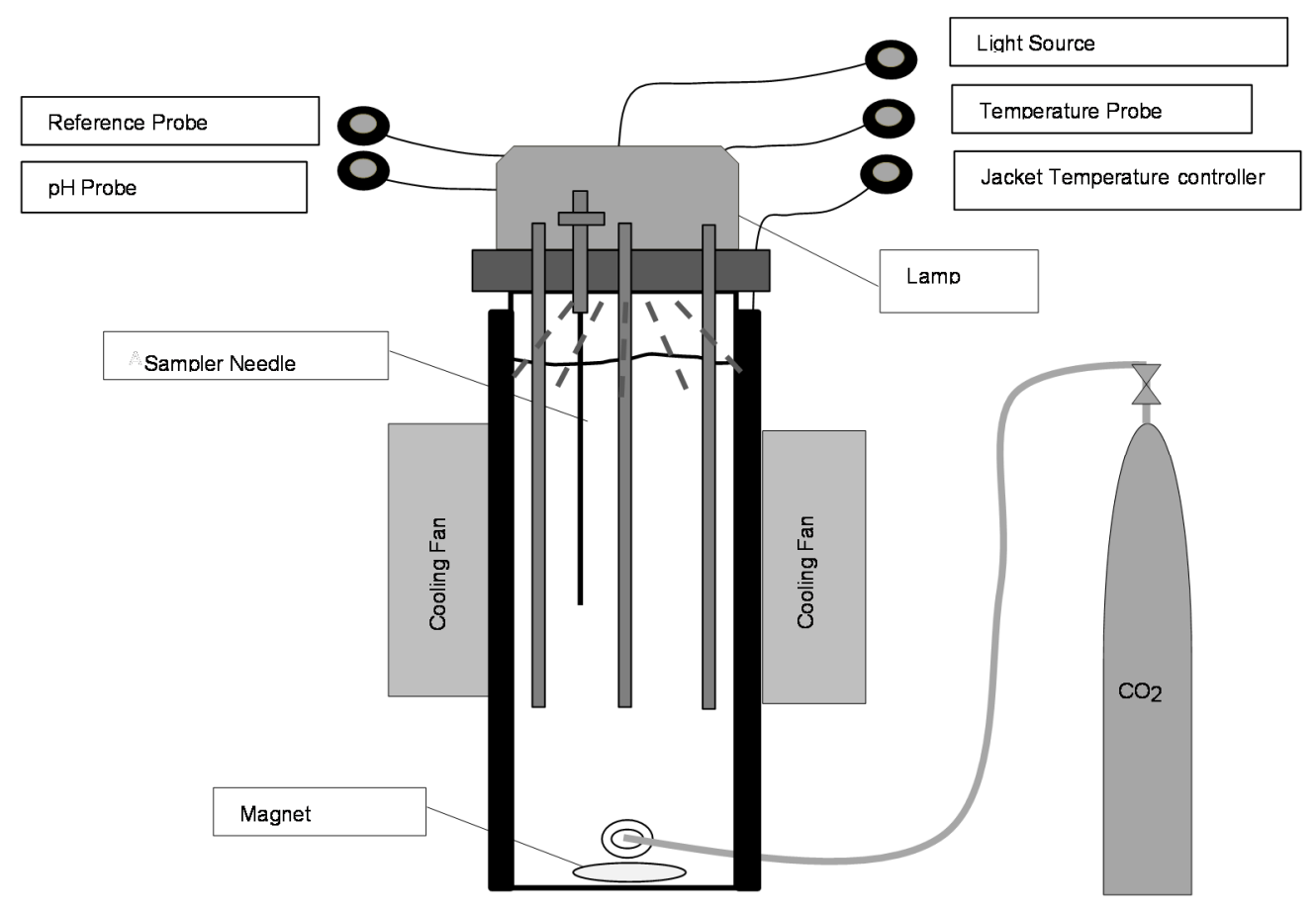

Figure 1. Schematic representation of the Porphyridium cruentum photo bioreactor.

\subsection{Lipid Extraction}

Lipids were extracted using a modified procedure of Bligh and Dyer [37]. The dried algae were homogenized in a chloroform/methanol/water solution with a volume ratio of 1:2:0.8, respectively. Next, an equal volume of water and chloroform was added to the mixture to reach a final ratio of 2:2:1.8. This mixture was left at room temperature overnight. Afterwards, the mixture was filtered to remove the algae pellets and then allowed to resettle to obtain a two-phase mixture. The lower phase (chloroform layer) containing the lipids was isolated from the aqueous phase. The remaining aqueous phase and also the residues that remained on the filter were re-extracted with chloroform/methanol with a volume ratio of $2: 1$. The chloroform layers obtained from these two steps were combined together and dried to obtain the lipid content. The lipid contents were obtained by subtracting the weight of the empty flask from the flask containing lipids. The percentage of the lipid content was determined by Equation (3) [38]:

$$
\text { Lipid content } \%=\frac{\text { Weight of lipid }(\mathrm{mg})}{\text { Weight of dried microalgae biomass }(\mathrm{mg})} \times 100
$$

The lipid productivities were calculated using Equation (4) [39]:

$$
\text { Lipid productivity }(\mathrm{mg} / \text { Lday })=\frac{\text { Lipid content }(\mathrm{mg} / \mathrm{mg}) \times \text { Dried biomass content }(\mathrm{mg} / \mathrm{L})}{\text { Cultivation period (days) }}
$$

\subsection{Lipid Transmethylations}

Analysis of fatty acids through gas chromatography (GC) required extreme temperatures above the upper temperature limit of the stationary phase. For this reason, the free fatty acids were derivatized to methyl esters prior to GC analysis. First, every $10 \mathrm{mg}$ of lipid sample was mixed with $1 \mathrm{~mL}$ of toluene 
and $1 \mathrm{~mL}$ of $1.5 \%$ sulfuric acid in dry methanol. Second, the mixture was incubated at $55{ }^{\circ} \mathrm{C}$ overnight. Third, $2 \mathrm{~mL}$ of saturated $\mathrm{NaCl}$ solution was added and vortexed. Finally, $1 \mathrm{~mL}$ of hexane was added followed by $1.5 \mathrm{~mL}$ of sodium hydrogen carbonate $\left(2 \% \mathrm{NaHCO}_{3}\right)$. The mixture was vortexed and the upper phase was taken for analysis via GC [38].

\subsection{Gas Chromatography Analysis}

The analysis of fatty acid methyl esters (FAME) was performed using a gas chromatograph GC-2014 (Shimadzu, Columbia, MD, USA), equipped with an auto-sampler and a flame ionization detector (FID). A Zebron ${ }^{\mathrm{TM} Z B}-\mathrm{FFAP}$ polar capillary column $(30 \mathrm{~m} \times 0.32 \mathrm{~mm} \times 0.25 \mu \mathrm{m}$ film thickness; Phenomenex, Torrance, CA, USA) was used to separate the FAME. The carrier gas was helium at a linear velocity of $35 \mathrm{~cm} / \mathrm{s}$. The column was subjected to a temperature program for separation as follows: initial column oven temperature of $150{ }^{\circ} \mathrm{C}$ held for $3 \mathrm{~min}$, heating at $1.5^{\circ} \mathrm{C} / \mathrm{min}$ to $240{ }^{\circ} \mathrm{C}$ and sustained for $15 \mathrm{~min}$. The injector (FAME samples of $2 \mu \mathrm{L}$ each and split ratio 10:1) and detector temperature were kept constant at $250{ }^{\circ} \mathrm{C}$ during the 78-min analysis. The compounds were identified and quantified by comparing the peaks with Marine Oil Test Mix (Restek Corp., Bellefonte, PA, USA) FAME standards. The provided GC data are based on duplicate measurements.

\section{Results and Discussion}

\subsection{Light Intensity, Temperature, and $\mathrm{CO}_{2}$ Supplementation}

\subsubsection{Cell Densities and Growth Rates}

The effects of light intensity and temperature as well as $\mathrm{CO}_{2}$ supplementation on cell densities and growth rates of $P$. cruentum were investigated. Illumination was fixed at two different intensities $\left(140 \mu \mathrm{E} \mathrm{m}^{-2} \mathrm{~s}^{-1}\right.$ and $\left.180 \mu \mathrm{E} \mathrm{m}^{-2} \mathrm{~s}^{-1}\right)$ and a day/night light cycle of $13 / 11 \mathrm{~h}$. The culture was harvested in the stationary phase after approximately 30 days. Figure 2 shows the effect of light intensity on the cell density of $P$. cruentum during growth at $20{ }^{\circ} \mathrm{C}$.

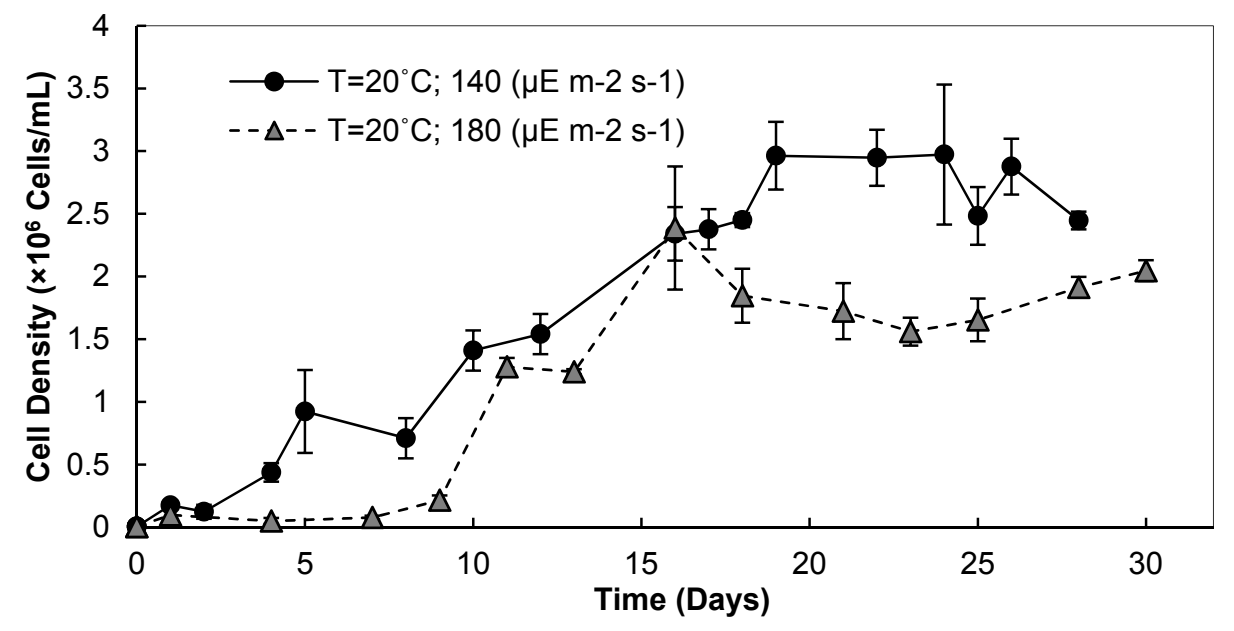

Figure 2. Cell density $\left(\times 10^{6}\right.$ cell $\left./ \mathrm{mL}\right)$ of $P$. cruentum at different light intensities of $140 \mu \mathrm{E} \mathrm{m}^{-2} \mathrm{~s}^{-1}$ and $180 \mu \mathrm{E} \mathrm{m}^{-2} \mathrm{~s}^{-1}$. 
The cell density for the light intensity of $140 \mu \mathrm{E} \mathrm{m}^{-2} \mathrm{~s}^{-1}$ increased during the growth time without any obvious lag phase. The maximum cell density was approximately $3.0 \times 10^{6}$ cells per mL on day 19. However, there was a lag time (about 7 days) at the growth in the light intensity of $180 \mu \mathrm{E} \mathrm{m}^{-2} \mathrm{~s}^{-1}$. Nevertheless, at this light intensity the growth rate increased rapidly after seven days, reaching maximum cell numbers on day $16\left(2.4 \times 10^{6}\right.$ cells per $\left.\mathrm{mL}\right)$. In addition, the effect of temperature on the growth at $140 \mu \mathrm{E} \mathrm{m}^{-2} \mathrm{~s}^{-1}$ is shown in Figure 3. Cell densities were reduced at lower temperatures with longer lag times. The maximum cell density $\left(2.02 \times 10^{6}\right.$ cells per $\left.\mathrm{mL}\right)$ occurred on day 20 . The results indicate that higher light intensity and lower temperature result in longer lag times and lower cell densities.

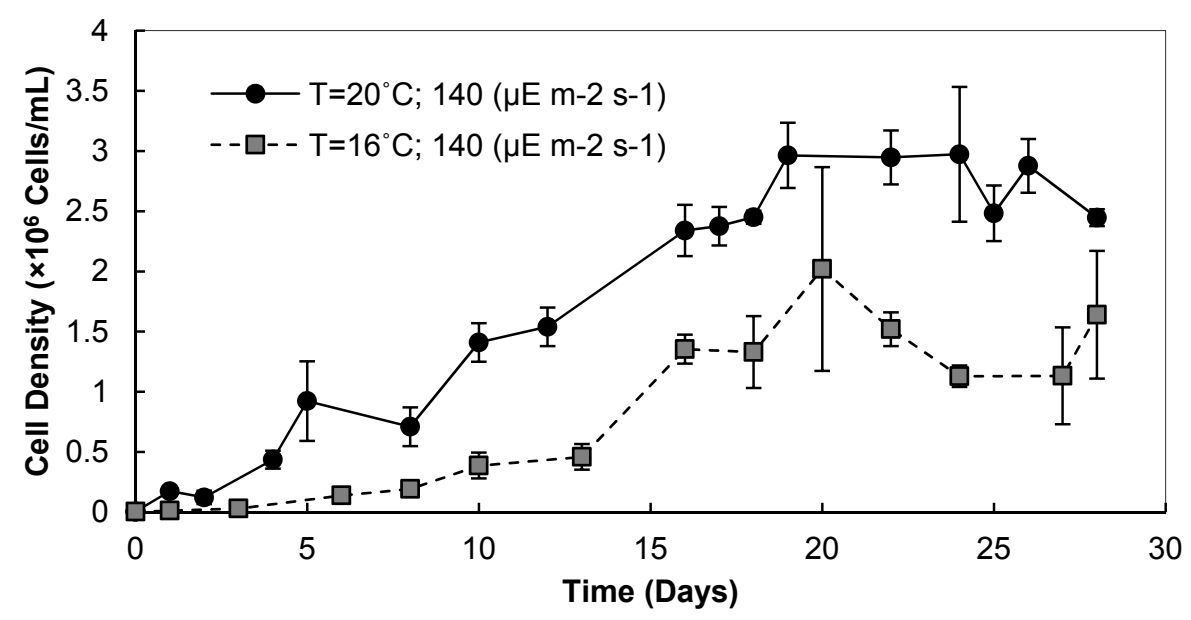

Figure 3. Cell density $\left(\times 10^{6}\right.$ cell $\left./ \mathrm{mL}\right)$ of $P$. cruentum at different growth temperatures of $16^{\circ} \mathrm{C}$ and $20^{\circ} \mathrm{C}$.

The effect of culture gassing with carbon dioxide was studied by providing $\mathrm{CO}_{2}$ and $5 \% \mathrm{CO}_{2}$ in air. Carbon dioxide caused a change in culture $\mathrm{pH}$ in addition to other physiological effect on cells [19]. The cell densities are shown in Figure 4. Algal growths were approximately the same for both conditions in the early growth phase but after about 12 days cell densities declined when $5 \% \mathrm{CO}_{2} /$ air was used as $\mathrm{CO}_{2}$ supplementation.

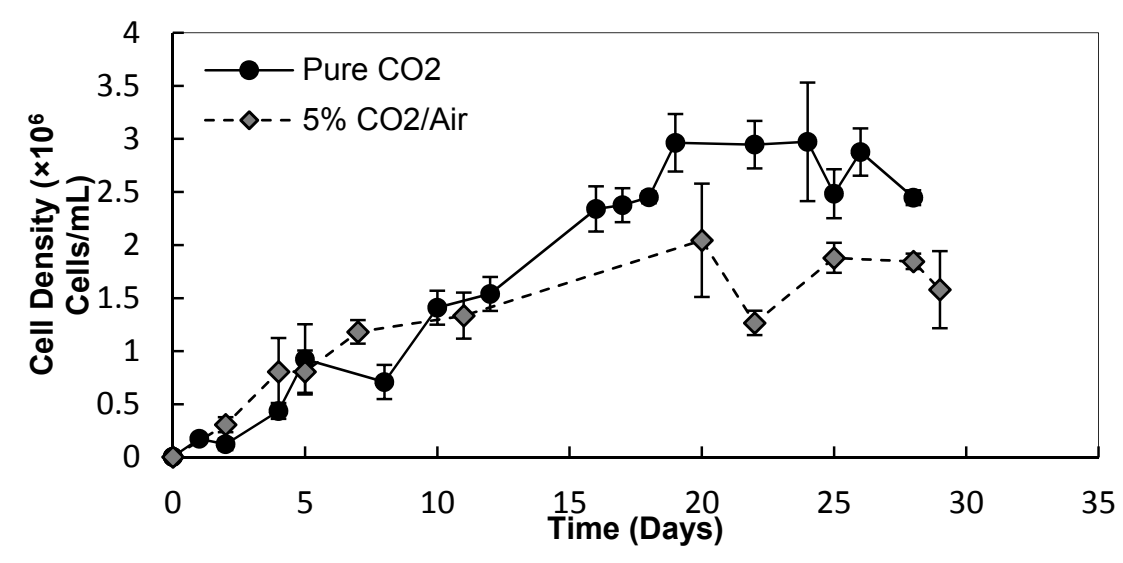

Figure 4. Effect of $\mathrm{CO}_{2}$ supplementation on cell density $\left(\times 10^{6}\right.$ cell $\left./ \mathrm{mL}\right)$ of $P$. cruentum at optimum temperature $\left(20^{\circ} \mathrm{C}\right)$ and light intensity $\left(140 \mu \mathrm{E} \mathrm{m}^{-2} \mathrm{~s}^{-1}\right)$ and nitrogen concentration (0.075 g nitrate/L). 
Figure 5 presents the effect of temperature and light intensity as well as $\mathrm{CO}_{2}$ supplementation on growth rates $(\mu)$ of $P$. cruentum. Growth rates were not significantly affected by temperature and $\mathrm{CO}_{2}$ supplementation. Interestingly we also see very little difference between using pure carbon dioxide and a mixture that is more representative of what would be seen by flue gas. This suggests that this alga is quite amenable to using a waste carbon dioxide source.

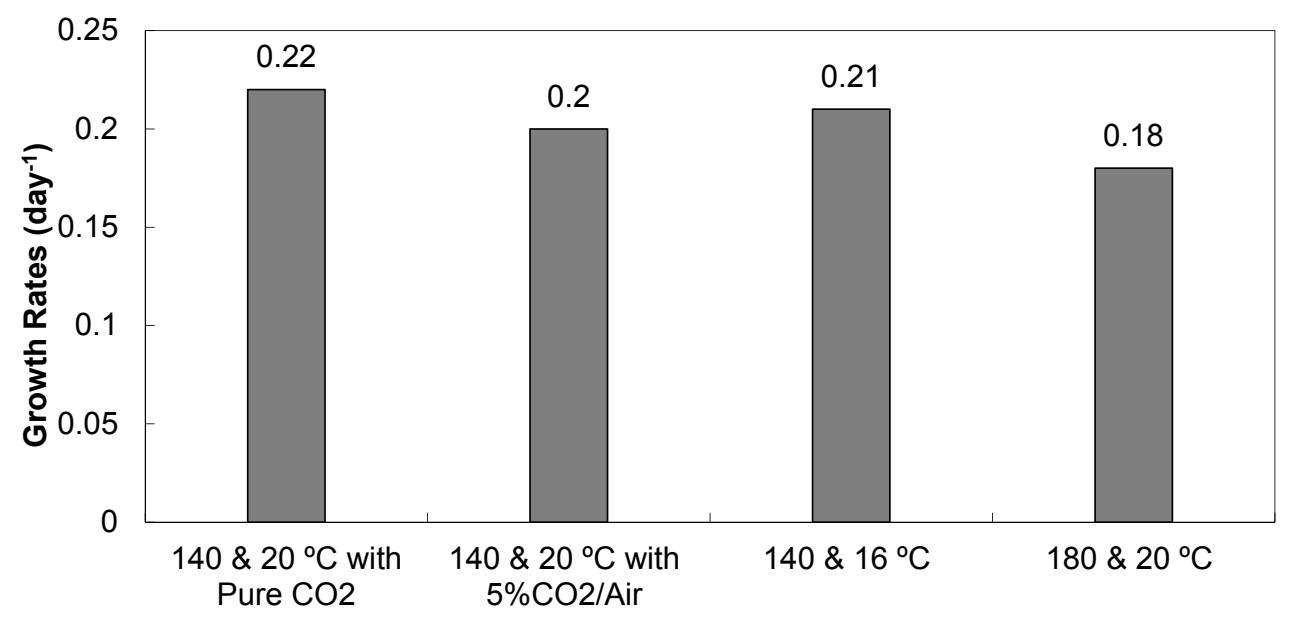

Light Intensity $\left(\mu \mathrm{E} \mathrm{m} \mathrm{m}^{-2} \mathrm{~s}^{-1}\right)$ and Temperature $\left({ }^{\circ} \mathrm{C}\right)$

Figure 5. The effect of temperature and light intensity as well as $\mathrm{CO}_{2}$ supplementation on growth rates $(\mu)$ of $P$. cruentum.

\subsubsection{Biomass and Lipid Contents}

The effects of light intensity, temperature, and $\mathrm{CO}_{2}$ supplementation on the biomass productivities, lipid contents and lipid productivities of $P$. cruentum are shown in Figure 6. Increased lipid productivity and lipid content were observed when $5 \% \mathrm{CO}_{2}$ in air was used. However, the biomass productivity was lower compared to pure $\mathrm{CO}_{2}$ supplementation. As seen in Figure 6, decreased temperature and enhanced light intensity resulted in a significant change in cell composition, favoring the accumulation of lipid components during the batch growth of $P$. cruentum. In previous studies involving Porphyridium cruentum [32], lipid levels were measured between $9 \%$ and $14 \%$ per dry weight. However, in this study, the lipid levels of the $P$. cruentum cells were substantially lower $(0.5 \%-1.6 \%)$. This is possibly due to the difference in strains or culture medium compositions. Lipid contents increased from $0.85 \%$ to $0.98 \%$ and $1.1 \%$ with decreased temperature (from $20{ }^{\circ} \mathrm{C}$ to $16{ }^{\circ} \mathrm{C}$ )

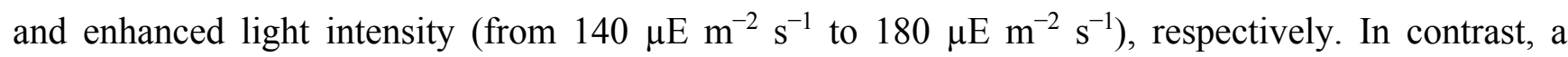
decrease in the growth temperature from $20{ }^{\circ} \mathrm{C}$ to $16{ }^{\circ} \mathrm{C}$ led to a diminution in biomass productivity of P. cruentum from $92 \mathrm{mg} \mathrm{L}^{-1}$ day $^{-1}$ to $63 \mathrm{mg} \mathrm{L}^{-1}$ day $^{-1}$. Moreover, biomass productivity reduced from $92 \mathrm{mg} \mathrm{L}^{-1}$ day $^{-1}$ to $59 \mathrm{mg} \mathrm{L}^{-1}$ day $^{-1}$ by increasing light intensity from $140 \mu \mathrm{E} \mathrm{m}^{-2} \mathrm{~s}^{-1}$ to $180 \mu \mathrm{E} \mathrm{m}^{-2} \mathrm{~s}^{-1}$. Lipid productivity considers both the biomass produced by microalgae cells and the lipid accumulations in these cells [26]. Comparing the lipid and biomass productivities shown in Figure 6, it can be seen that higher biomass productivities did not result in higher lipid productivities. This result may be due to the stress conditions that lead to the accumulation of lipids in the cells and also to a reduction in microalgae biomass productivity. Microalgae replace cell production with lipid 
biosynthesis in cells under unfavorable environmental or stress conditions. The lipid productivities for different light intensities and temperatures are presented in Figure 6. Enhanced lipid productivities occurred at higher temperature $\left(0.62 \mathrm{mg} \mathrm{L}^{-1}\right.$ day $^{-1}$ to $0.78 \mathrm{mg} \mathrm{L}^{-1}$ day $^{-1}$, for temperatures from $16^{\circ} \mathrm{C}$ to $\left.20{ }^{\circ} \mathrm{C}\right)$ and higher light intensity $\left(0.62 \mathrm{mg} \mathrm{L}^{-1}\right.$ day $^{-1}$ to $0.65 \mathrm{mg} \mathrm{L}^{-1} \mathrm{day}^{-1}$ for illuminations from $140 \mu \mathrm{E} \mathrm{m}^{-2} \mathrm{~s}^{-1}$ to $180 \mu \mathrm{E} \mathrm{m}^{-2} \mathrm{~s}^{-1}$ ). As presented in Figure 6, a similar trend was observed for lipid contents and productivities.

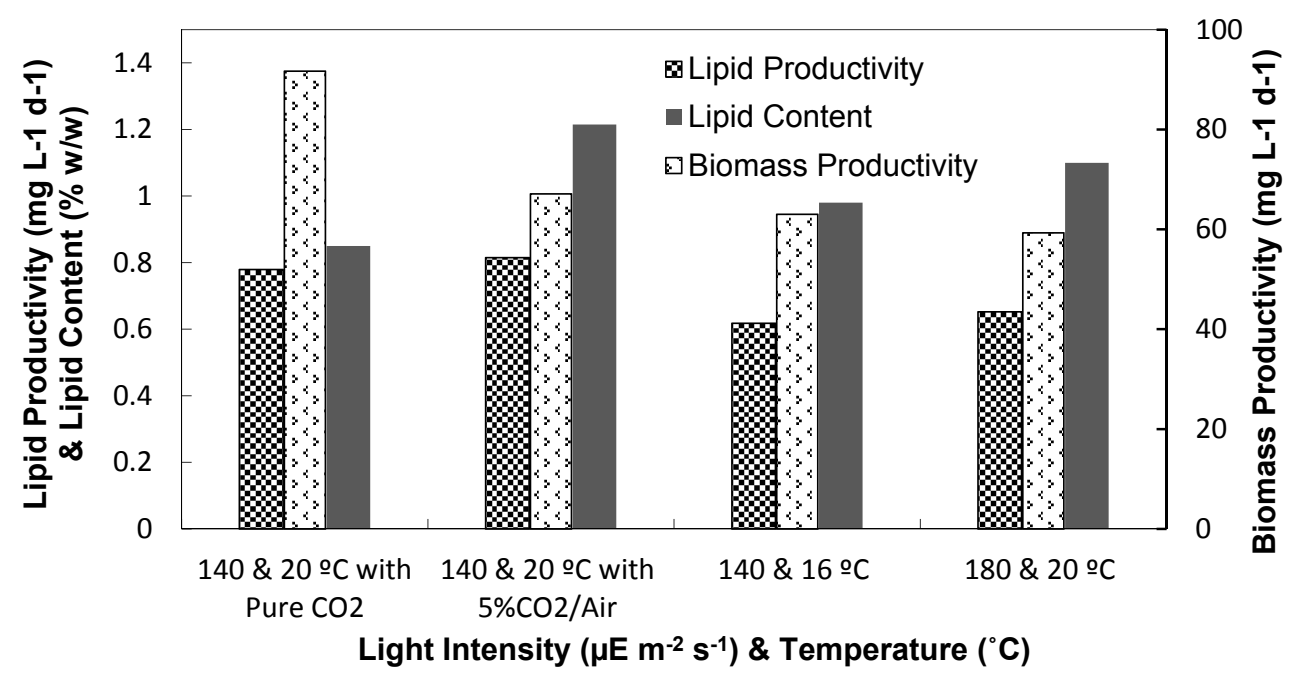

Figure 6. Biomass productivity, lipid contents, and lipid productivity of $P$. cruentum at different light intensities and temperatures as well as $\mathrm{CO}_{2}$ supplementation.

\subsubsection{Fatty Acid Compositions}

The fatty acid compositions were related to growth conditions such as temperature and illumination as well as nutrient levels. As presented in Table 1, the major fatty acids from P. cruentum were C16:0 (palmitic acid; 25.0\%-30.6\%), C18:2 (linoleic acid; 12.4\%-27.6\%), C20:4 (ARA; 23.4\%-30.5\%) and C20:5 (EPA; 6.7\%-13.1\%). In addition, it contained low levels of C14:0 (myristic acid; 0.2\%-0.3\%), C14:1 (myristoleic acid; 0.1\%-0.4\%), C16:1 (palmitoleic acid; 0.2\%-2.8\%), C18:0 (stearic acid; $1.5 \%-3.5 \%$ ), C18:1-Cis-9 (oleic acid; 1.3\%-4.3\%), C18:1-trans (octadecenoic acid; 0.3\%-0.8\%), C18:3 (linolenic acid; 0.1\%-0.4\%), C20:2 (eicosadienoic acid; 0.8\%-2.5\%), and C22:1 (erucic acid; 1.2\%), as well as trace amounts of C20:0 (arachidic acid), C20:1 (11-eicoenoic acid), and C20:3 (11-14-17 eicosatrienoic acid). Unknown fatty acids were about 4.6\%-7.7\%. Additionally, there was no trace of C22:6 (DHA) in the P. cruentum. These data are in agreement with Cohen et al. [40]. However, Oh et al. [41] exhibited considerable amounts of DHA without any EPA from P. cruentum cells grown under different light and dark cycles.

The effects of light intensity and temperature as well as $\mathrm{CO}_{2}$ supplementation on the percentage of EPA and ARA in total lipid contents are presented in Figure 7. Decreasing temperature (from $20^{\circ} \mathrm{C}$ to $16{ }^{\circ} \mathrm{C}$ ) led to higher percentages of EPA (from 9.5\% to 9.9\%) and ARA (from $23.9 \%$ to $26.2 \%$ ). In addition, the ratio of ARA to EPA was increased slightly from 2.5 to 2.6 at a lower temperature. An analysis of the data of Cohen et al. [40] reveals a similar variation in the EPA value in response to changes in temperature from $30{ }^{\circ} \mathrm{C}$ to $25{ }^{\circ} \mathrm{C}$. A further drop in the growth temperature to $20{ }^{\circ} \mathrm{C}$ produced a reduction in the proportion of EPA. Their results also showed a decrease in ARA values 
with reducing the growth temperature and the culture should be maintained at $30{ }^{\circ} \mathrm{C}$ for optimal ARA production with a minimum proportion of EPA.

Table 1. Fatty acid compositions of $P$. cruentum strain ( $\%$ of total fatty acids).

ARA: arachidonic acid; EPA: eicosapentaenoic acid; DHA: docosahexaenoic acid.

\begin{tabular}{|c|c|c|c|c|c|c|c|c|}
\hline \multicolumn{2}{|c|}{$\boldsymbol{T}\left({ }^{\circ} \mathbf{C}\right)$} & 20 & 20 & 16 & 20 & 20 & 20 & 20 \\
\hline \multicolumn{2}{|c|}{ 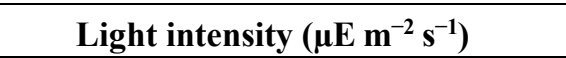 } & 140 & 140 & 140 & 180 & 140 & 140 & 140 \\
\hline \multicolumn{2}{|c|}{ Nitrate concentrations } & 0.075 & $\begin{array}{c}0.075 \text { (5\% } \\
\mathrm{CO}_{2} / \text { Air) }\end{array}$ & 0.075 & 0.075 & 0.3 & 0.5 & 0.7 \\
\hline \multirow{7}{*}{ Saturated } & $\mathrm{C} 14: 0$ & - & $0.2 \%$ & - & - & $0.2 \%$ & $0.3 \%$ & $0.3 \%$ \\
\hline & $\mathrm{C} 16: 0$ & $30.5 \%$ & $25.0 \%$ & $27.7 \%$ & $26.6 \%$ & $29.6 \%$ & $27.4 \%$ & $30.6 \%$ \\
\hline & $\mathrm{C} 18: 0$ & $2.5 \%$ & $3.1 \%$ & $3.0 \%$ & $3.5 \%$ & $1.5 \%$ & $2.3 \%$ & $2.9 \%$ \\
\hline & $\mathrm{C} 20: 0$ & - & $0.1 \%$ & - & - & $0.1 \%$ & - & - \\
\hline & $\mathrm{C} 22: 0$ & - & - & - & - & - & - & - \\
\hline & $\mathrm{C} 24: 0$ & - & - & - & - & - & - & - \\
\hline & Total & $33.0 \%$ & $28.3 \%$ & $30.7 \%$ & $30.1 \%$ & $31.3 \%$ & $29.9 \%$ & $33.7 \%$ \\
\hline \multirow{8}{*}{ Mono-unsaturated } & $\mathrm{C} 14: 1$ & - & - & - & - & - & $0.1 \%$ & $0.4 \%$ \\
\hline & C16:1 & $1.0 \%$ & $0.2 \%$ & $1.0 \%$ & $1.0 \%$ & $0.2 \%$ & $2.0 \%$ & $2.8 \%$ \\
\hline & C18:1 (cis-9) & $3.2 \%$ & $3.9 \%$ & $3.8 \%$ & $4.3 \%$ & $1.3 \%$ & $2.3 \%$ & $1.6 \%$ \\
\hline & C18:1 (trans) & - & $0.3 \%$ & - & - & $0.7 \%$ & $0.4 \%$ & $0.8 \%$ \\
\hline & $\mathrm{C} 20: 1$ & - & $0.2 \%$ & - & - & $0.1 \%$ & $0.1 \%$ & - \\
\hline & $\mathrm{C} 22: 1$ & $1.2 \%$ & - & - & - & - & - & - \\
\hline & $\mathrm{C} 24: 1$ & - & - & - & - & - & - & - \\
\hline & Total & $5.4 \%$ & $4.5 \%$ & $4.8 \%$ & $5.3 \%$ & $2.3 \%$ & $5.0 \%$ & $5.5 \%$ \\
\hline \multirow{8}{*}{ Poly-unsaturated } & C18:2 & $21.0 \%$ & $24.6 \%$ & $22.4 \%$ & $27.6 \%$ & $12.8 \%$ & $19.5 \%$ & $12.4 \%$ \\
\hline & C18:3 & - & $0.1 \%$ & - & - & $0.1 \%$ & $0.4 \%$ & - \\
\hline & $\mathrm{C} 20: 2$ & $0.8 \%$ & $1.9 \%$ & $1.1 \%$ & $1.3 \%$ & $2.1 \%$ & $2.5 \%$ & $1.7 \%$ \\
\hline & C20:4 (ARA) & $23.9 \%$ & $26.1 \%$ & $26.2 \%$ & $23.4 \%$ & $30.5 \%$ & $25.1 \%$ & $29.1 \%$ \\
\hline & $\mathrm{C} 20: 3$ & - & $0.1 \%$ & - & - & $0.1 \%$ & $0.1 \%$ & - \\
\hline & C20:5 (EPA) & $9.5 \%$ & $8.7 \%$ & $9.9 \%$ & $6.7 \%$ & $13.1 \%$ & $11.5 \%$ & $13.1 \%$ \\
\hline & C22:6 (DHA) & - & - & - & - & - & - & - \\
\hline & Total & $55.2 \%$ & $61.3 \%$ & $59.5 \%$ & $59.0 \%$ & $58.8 \%$ & $59.1 \%$ & $56.3 \%$ \\
\hline Unknown FAs & & $6.4 \%$ & $5.8 \%$ & $5.1 \%$ & $5.6 \%$ & $7.7 \%$ & $6.1 \%$ & $4.6 \%$ \\
\hline
\end{tabular}

Cohen [17] also illustrated that the range of ARA/EPA values in the exponential phase at $25{ }^{\circ} \mathrm{C}$ was $0.33-0.63$. However, this ratio increased to $0.86-2.1$ at the stationary phase as ARA increased while the EPA levels decreased drastically. According to their results, P. cruentum contained more than $39 \%$ of total fatty acids as ARA and only $6.6 \%-14.2 \%$ as EPA with ARA/EPA values of $1.7-6.1$ when exponentially cultivated under the same light intensity at $30^{\circ} \mathrm{C}$. The ARA/EPA values at the stationary phase were higher, 2.3-11.5. Akimoto et al. [42] showed an increase in EPA and decrease in ARA and consequently reduced the ARA to EPA ratio by decreasing the temperature from $32{ }^{\circ} \mathrm{C}$ to $20{ }^{\circ} \mathrm{C}$. We suggest that this disagreement could possibly stem from the different culture medium and other factors such as environmental and nutrient conditions that govern the fatty acid composition of the alga. In addition, none of these studies investigated a temperature below $20^{\circ} \mathrm{C}$. 
Light intensity affects the fatty acid composition, especially the proportion of ARA and EPA and the ratio of ARA to EPA. The proportion of EPA increased considerably from $6.7 \%$ to $9.5 \%$ when the light intensity was reduced from $180 \mu \mathrm{E} \mathrm{m}^{-2} \mathrm{~s}^{-1}$ to $140 \mu \mathrm{E} \mathrm{m}^{-2} \mathrm{~s}^{-1}$, while the ARA amounts slightly increased from $23.4 \%$ to $23.9 \%$ with decreased light intensity. Consequently, ARA to EPA ratio showed a reduced trend with reduction in light intensity. These results are in agreement with Akimoto et al. [42], who reported an enhanced ARA and EPA contents from P. cruentum by decreasing light intensity at a growth temperature of $30^{\circ} \mathrm{C}$.

ARA was higher when $5 \% \mathrm{CO}_{2} /$ Air was used compared to pure $\mathrm{CO}_{2}$, as shown in Figure 7. In addition, 5\% $\mathrm{CO}_{2} /$ Air caused an $8.5 \%$ reduction in EPA amounts. ARA contents are higher than EPA for all four conditions. As reported in previous studies [12], lower ratios of ARA to EPA lead to easier separations of ARA from EPA. Furthermore, since EPA with a certain level of ARA is required for optimal healthy nutrition, ARA to EPA ratio is a prominent parameter. The lowest and highest amounts of this ratio (2.5 and 3.4) occurred on $140 \mu \mathrm{E} \mathrm{m} \mathrm{m}^{-2} \mathrm{~s}^{-1}, 20{ }^{\circ} \mathrm{C}$ (with pure $\mathrm{CO}_{2}$ ) and $180 \mu \mathrm{E} \mathrm{m}^{-2} \mathrm{~s}^{-1}, 20{ }^{\circ} \mathrm{C}$, respectively. Since the goal is to achieve the lowest ARA/EPA or omega- 6 to omega-3 ratio, $20{ }^{\circ} \mathrm{C}$ and $140 \mu \mathrm{E} \mathrm{m}^{-2} \mathrm{~s}^{-1}$ (with pure $\mathrm{CO}_{2}$ ) are the optimum environmental growth conditions for P. cruentum.

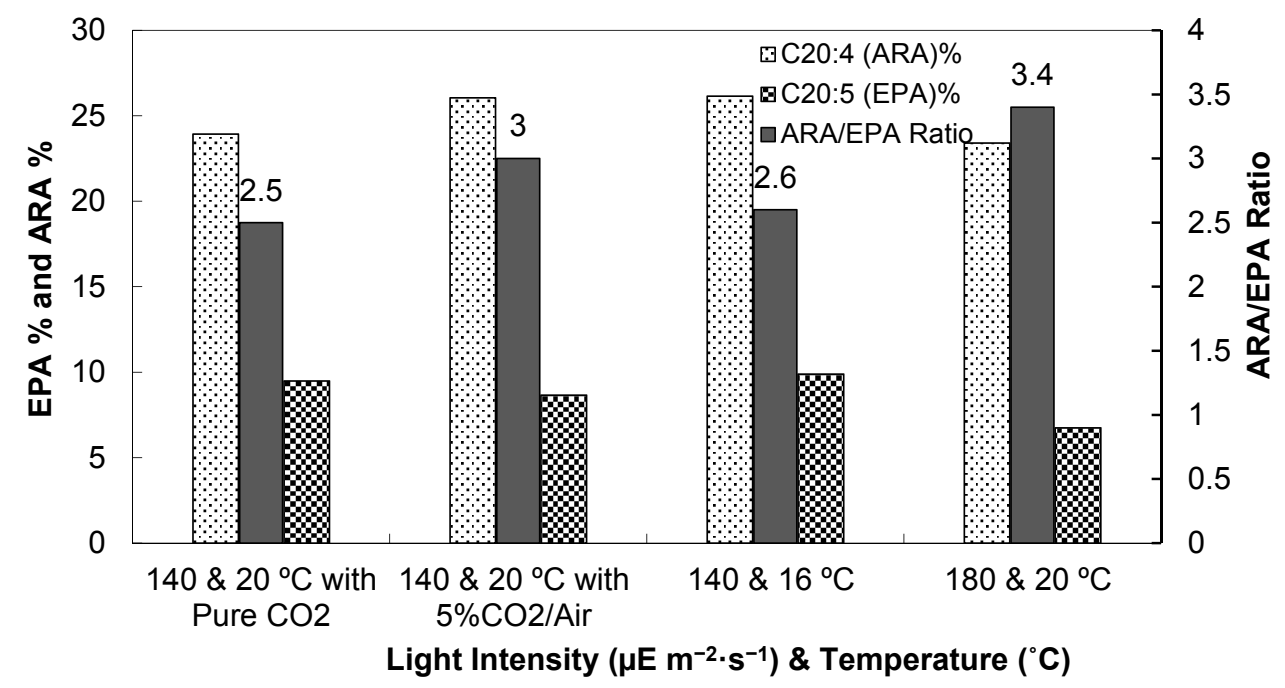

Figure 7. Effect of illumination and temperature on the EPA and ARA contents of P. cruentum.

\subsection{Nitrate Concentration}

\subsubsection{Cell Densities and Growth Rates}

The effect of nitrogen concentration on the cell growth and fatty acid compositions of $P$. cruentum, in modified L1-media containing $0.075,0.3,0.5$, or $0.7 \mathrm{~g} / \mathrm{L}$ sodium nitrate, was tested. The cell growth profile of $P$. cruentum obtained with different nitrate concentrations during growth time are shown in Figure 8 . The cell density of $P$. cruentum reached the maximum amounts $\left(0.45 \times 10^{6}\right.$ cells per $\mathrm{mL}$ and $1.3 \times 10^{6}$ cells per $\mathrm{mL}$ ) on days 14 and 23 in the medium containing $0.5 \mathrm{~g} / \mathrm{L}$ and $0.7 \mathrm{~g} / \mathrm{L}$ nitrate, respectively. The cell density improved significantly when the sodium nitrate concentration decreased to $0.3 \mathrm{~g} / \mathrm{L}$ and $0.075 \mathrm{~g} / \mathrm{L}$ (maximum values of approximately $3.0 \times 10^{6}$ cells per $\mathrm{mL}$ on day 30 and 19 , respectively). In addition, smaller lag times were observed with reduced nitrogen concentrations. 


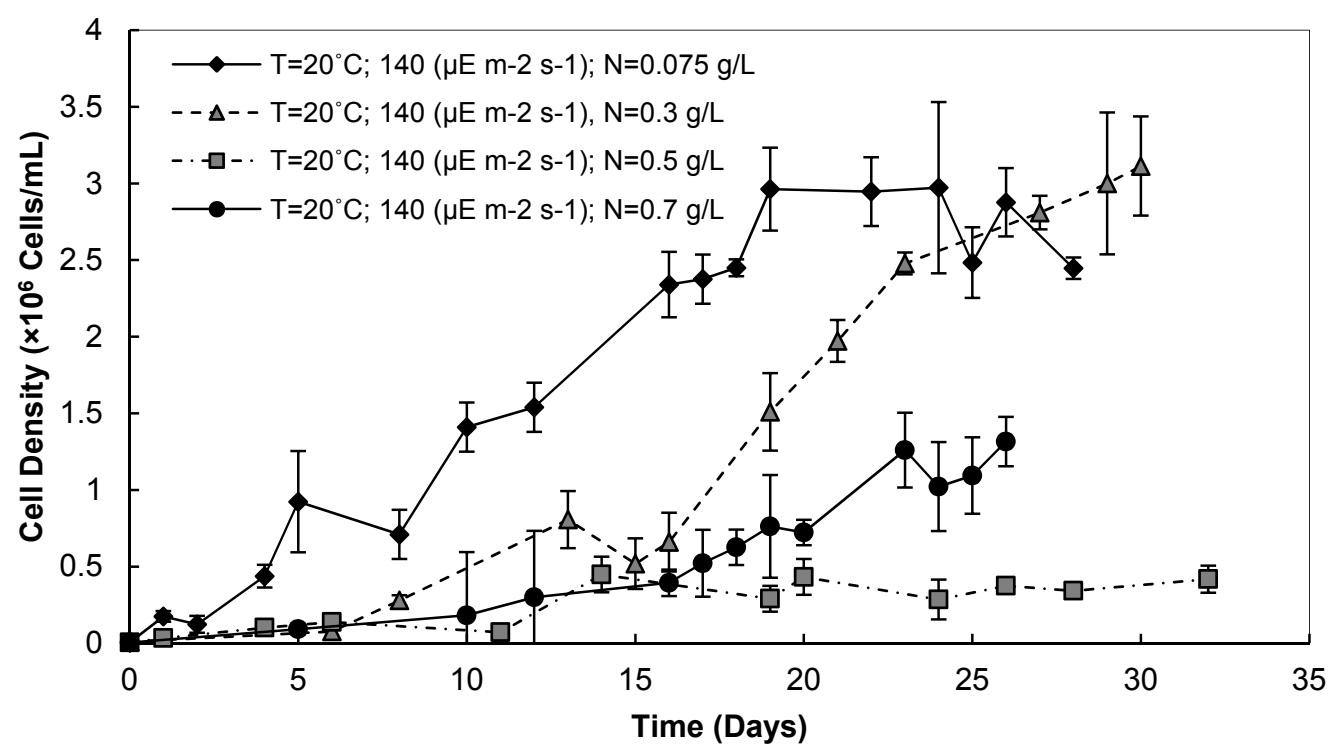

Figure 8. Cell density $\left(\times 10^{6}\right.$ cell/mL) of $P$. cruentum at optimum temperature $\left(20{ }^{\circ} \mathrm{C}\right)$ and light intensity $\left(140 \mu \mathrm{E} \mathrm{m}^{-2} \mathrm{~s}^{-1}\right)$ with different growth nutrient levels $(0.075,0.3,0.5$, or $\left.0.7 \mathrm{~g} \mathrm{NaNO}_{3} / \mathrm{L}\right)$.

The effect of increased nitrate concentration on growth rates $(\mu)$ of P. cruentum is shown in Figure 9. Growth rate amounts were calculated by Equation (1). The microalga grew most robustly in the medium containing $0.075 \mathrm{~g} / \mathrm{L}$ nitrate, reaching a specific growth rate of 0.22 day $^{-1}$. Conversely, in the medium with $0.5 \mathrm{~g} / \mathrm{L}$ nitrate, the specific growth rate was the lowest at 0.14 day $^{-1}$. Growth rates decreased by $14 \%$ and then $26 \%$ with an increase in nitrate concentration from $0.075 \mathrm{~g} / \mathrm{L}$ to $0.3 \mathrm{~g} / \mathrm{L}$ and $0.5 \mathrm{~g} / \mathrm{L}$, respectively. In addition, a higher growth rate $\left(0.17\right.$ day $\left.^{-1}\right)$ was observed for the medium containing $0.7 \mathrm{~g} / \mathrm{L}$ nitrate.

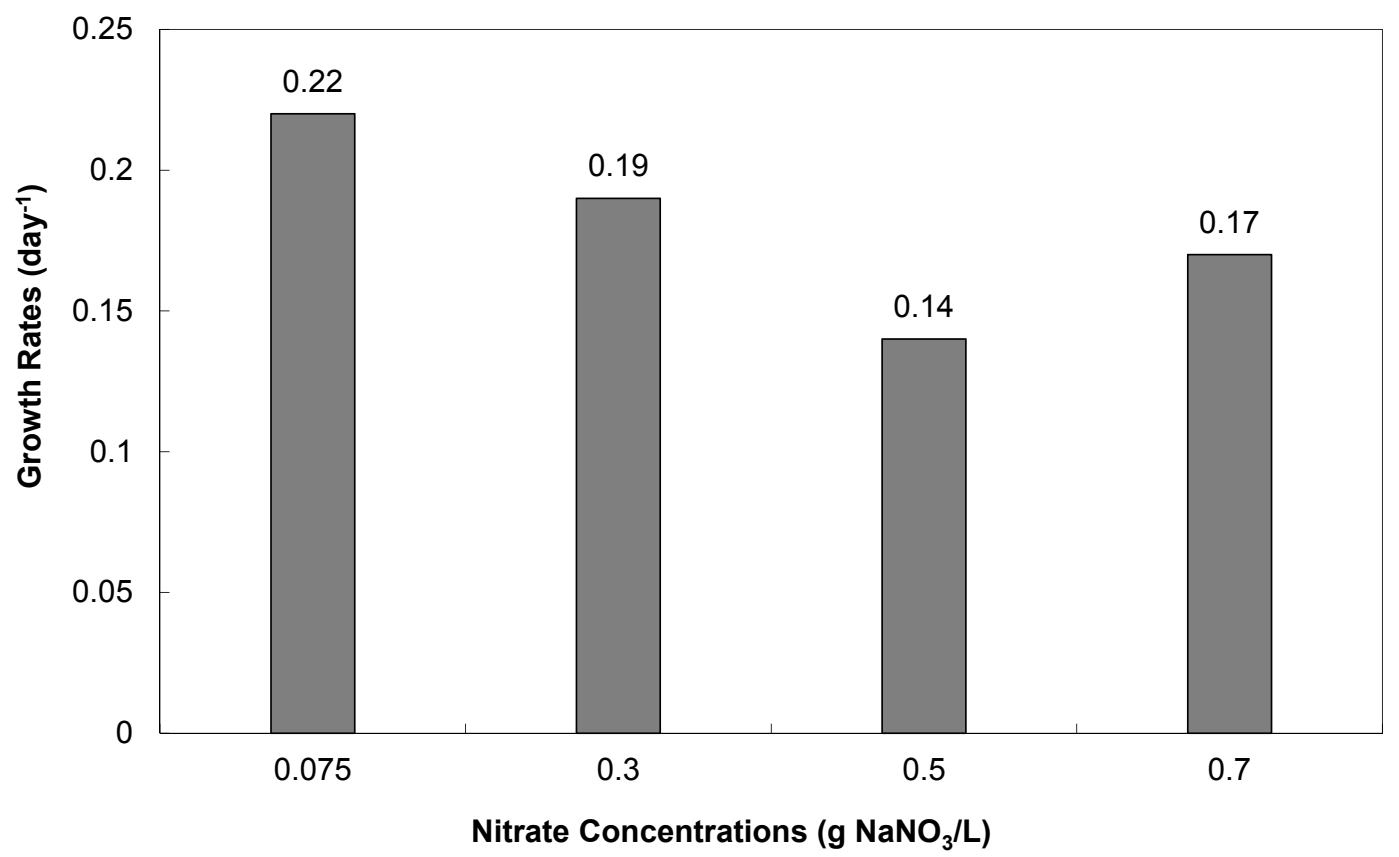

Figure 9. The effect of nitrate concentration on growth rates $(\mu)$ of P. cruentum. 


\subsubsection{Biomass and Lipid Contents}

Algal biomass was harvested from the culture at the stationary phase and subjected to the Bligh and Dyer [37] method to extract lipids from cells. Figure 10 demonstrates the effect of nitrate concentration on lipid contents as well as biomass and lipid productivities of $P$. cruentum at $20^{\circ} \mathrm{C}$ and $140 \mu \mathrm{E} \mathrm{m}^{-2} \mathrm{~s}^{-1}$. As shown in Figure 10, the biomass obtained from the medium with a nitrate concentration of $0.3 \mathrm{~g} / \mathrm{L}$ has the highest biomass productivity, $143 \mathrm{mg} \mathrm{L}^{-1}$ day $^{-1}$, followed by $0.075 \mathrm{~g} / \mathrm{L}$ and $0.5 \mathrm{~g} / \mathrm{L}$ nitrate, $79 \mathrm{mg} \mathrm{L}^{-1} \mathrm{day}^{-1}$ and $54 \mathrm{mg} \mathrm{L}^{-1}$ day $^{-1}$, respectively. The smallest amount is at a nitrate level of 0.7 $\mathrm{g} / \mathrm{L}$, which is $30 \mathrm{mg} \mathrm{L}^{-1} \mathrm{day}^{-1}$. Figure 10 also demonstrates that lipid contents and biomass productivities have opposite trends. The lipid contents dropped about $70 \%$ with nitrate concentration of $0.3 \mathrm{~g} / \mathrm{L}$ compared to $0.075 \mathrm{~g} / \mathrm{L}$ and then went in the opposite direction. Clearly, maximum biomass contents do not lead to maximum lipid contents. These observations agree with those of Cohen et al. [43], and indicate that carbohydrate and lipid synthesis may be enhanced at the expense of protein synthesis when growth is slowed by any stressing factor, such as nutrient variation. Figure 10 also shows that lipid productivities declined with an increase in nitrate concentrations.

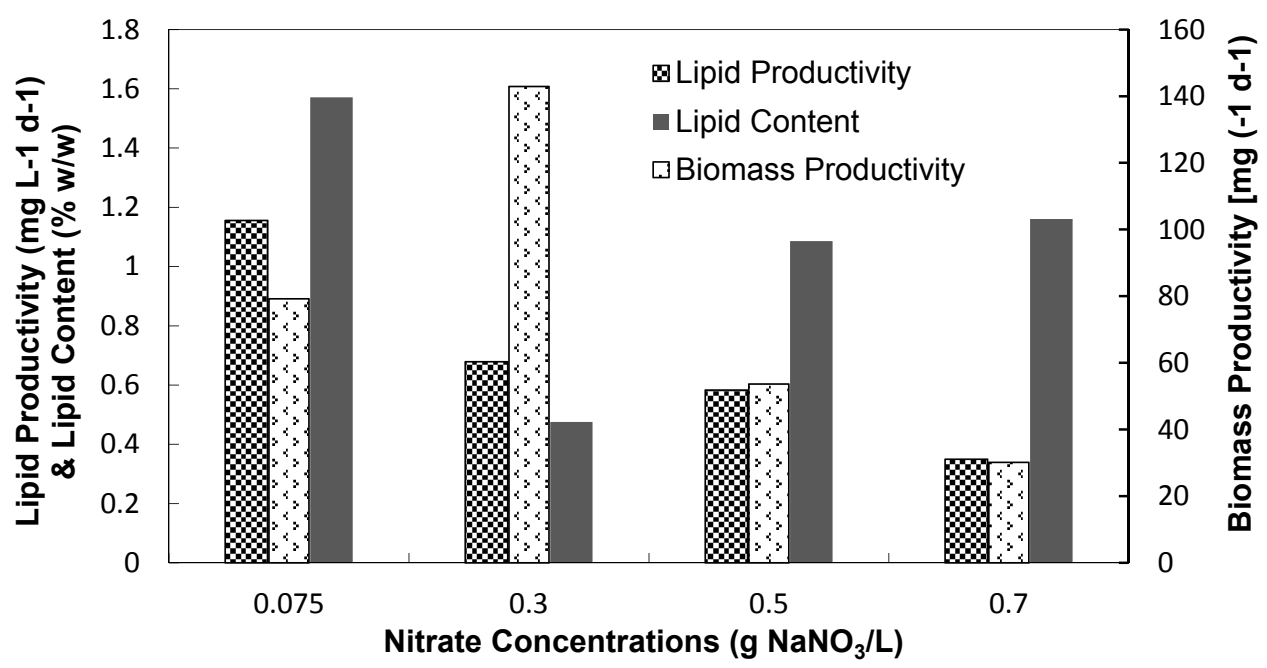

Figure 10. Biomass productivity, lipid contents, and lipid productivity of $P$. cruentum at optimum temperature $\left(20{ }^{\circ} \mathrm{C}\right)$ and light intensity $\left(140 \mu \mathrm{E} \mathrm{m}^{-2} \mathrm{~s}^{-1}\right)$ with different growth nutrient levels $\left(0.075,0.3,0.5\right.$, or $\left.0.7 \mathrm{~g} \mathrm{NaNO}_{3} / \mathrm{L}\right)$.

\subsubsection{Fatty Acid Compositions}

According to Table 1, the main fatty acids of $P$. cruentum in various nitrogen concentrations were the same as those described for different temperatures and light intensities. However, decreased amounts of 18:1 and 18:2 and enhanced 16:0, 16:1, 20:2, 20:4 (ARA), and 20:5 (EPA) were observed with increasing nitrogen concentrations. Figure 11 shows the percentage of EPA and ARA as well as their ratio (ARA/EPA) in lipids extracted from $P$. cruentum cells grown in different nitrate concentrations. The EPA percentages were approximately the same for two nitrate concentrations of $0.3 \mathrm{~g} / \mathrm{L}$ and $0.7 \mathrm{~g} / \mathrm{L}$. The experimental results showed that the highest lipid content does not induce the highest EPA amount. The EPA amounts were slightly decreased to $9.5 \%$ and $11.5 \%$ for $0.075 \mathrm{~g} / \mathrm{L}$ and $0.5 \mathrm{~g} / \mathrm{L}$ nitrate levels, respectively. Also, the same trend can be seen for the percentage of ARA 
extracted from $P$. cruentum. The highest and the lowest amounts of ARA were related to $0.3 \mathrm{~g} / \mathrm{L}$ and $0.075 \mathrm{~g} / \mathrm{L}$ nitrate, which were $30.5 \%$ and $24 \%$, respectively. Our results were similar to Cohen [17], who reported a decrease in 18:1 and 18:2 in nitrogen-sufficient culture compared to those under nitrogen starvation conditions while 16:0, 16:1, and EPA increased under nitrogen sufficient conditions. In addition, our experimental results showed a gradual reduction in ARA/EPA amounts (from 2.5 to 2.17), which is in agreement with Cohen [17] (from 3.0 to 0.7). Figure 11 shows that the smallest ratio of ARA/EPA occurred when the sodium nitrate concentration in the medium was $0.5 \mathrm{~g} / \mathrm{L}$. These results suggest that the optimal trade-off between maximizing biomass and lipid productivities as well as minimizing ARA/EPA ratio occurs at $20{ }^{\circ} \mathrm{C} \mu \mathrm{E} \mathrm{m}^{-2} \mathrm{~s}^{-1}$ and $140 \mu \mathrm{E} \mathrm{m} \mathrm{m}^{-2} \mathrm{~s}^{-1}$ with a nitrate concentration of $0.5 \mathrm{~g} / \mathrm{L}$ among the tested conditions.

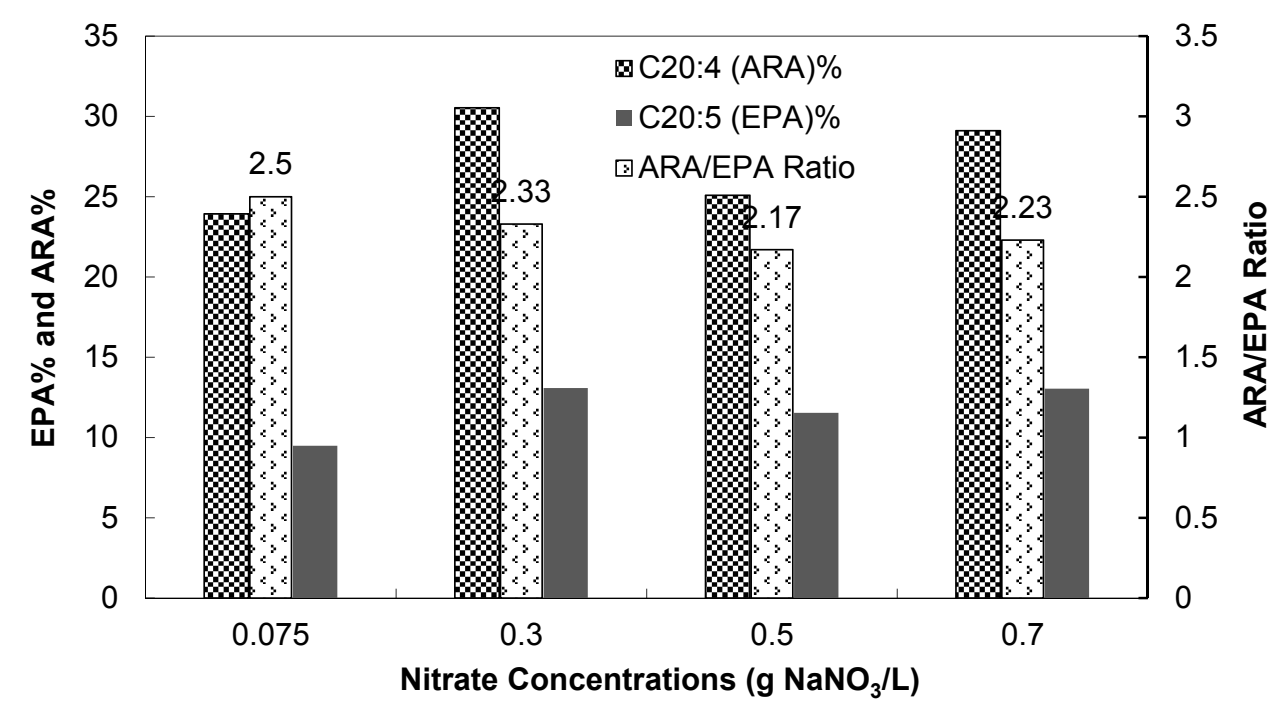

Figure 11. Effect of nitrogen level on EPA and ARA contents of P. cruentum.

\section{Conclusions}

This study demonstrates that temperature, illumination, nitrogen level, and $\mathrm{CO}_{2}$ levels in the growth media significantly impact the cell growth, lipid content, lipid productivity, and fatty acid compositions of $P$. cruentum. The results indicate that decreased temperature and enhanced light intensity result in higher lipid contents and lipid productivities as well as lower biomass productivities. Therefore, maximum biomass productivities do not lead to maximum lipid productivities. Synthesis and accumulation of higher lipid amounts occur in the cells when P. cruentum microalgae are placed under stress conditions imposed by physical environmental stimuli such as temperature and illumination. In addition, higher lipid productivity, lipid contents and lower biomass were observed when $5 \% \mathrm{CO}_{2}$ in air was used as $\mathrm{CO}_{2}$ supplementation. Higher ARA and lower EPA, and consequently a higher ARA/EPA ratio, was achieved with $5 \% \mathrm{CO}_{2}$ in air compared to pure $\mathrm{CO}_{2}$. Furthermore, the results demonstrate that $0.3 \mathrm{~g} / \mathrm{L}$ nitrate developed the highest biomass, $143 \mathrm{mg} \mathrm{L}^{-1}$ day $^{-1}$, while the minimum amount, $30 \mathrm{mg} \mathrm{L}^{-1} \mathrm{day}^{-1}$, was related to the medium with a nitrate concentration of $0.7 \mathrm{~g} / \mathrm{L}$. An opposite trend was observed for lipid contents. Also, the results showed that lipid productivities declined with an increase in nitrate concentrations. The fatty acid composition showed that the major fatty acids from P. cruentum were C16:0, C18:2, C20:4 (ARA), and C20:5 (EPA). As lower ratios of 
ARA to EPA lead to easier separations of EPA from ARA and also are desirable nutritionally, this study shows that the optimal growth conditions to produce the lowest ratio, 2.17 , was achieved at $20{ }^{\circ} \mathrm{C}$ and $140 \mu \mathrm{E} \mathrm{m}^{-2} \mathrm{~s}^{-1}$ (with pure $\mathrm{CO}_{2}$ ) and $0.5 \mathrm{~g} / \mathrm{L}$ nitrate.

\section{Acknowledgments}

The authors would like to acknowledge the financial contribution of the Arkansas Biosciences Institute (ABI). We thank Peggy Anderson and Alexander M. Lopez-Rosa of the Ralph E. Martin Department of Chemical Engineering at the University of Arkansas for their valuable comments during the writing of this article and Neda Mahmoudi, Thomas Potts, Tammy Lutz-Rechtin, Alice Jernigan, and Long Tran for their help in the laboratory.

\section{Author Contributions}

Maryam Asgharpour conducted the study and wrote the paper. Brigitte Rodgers participated in the preliminary experimental works. The work was performed under supervision of Jamie A. Hestekin who carefully edited the paper, provided technical support and guidance, and directly contributed the results of this article.

\section{Conflicts of Interest}

The authors declare no conflict of interest.

\section{References}

1. Spolaore, P.; Joannis-Cassan, C.; Duran, E.; Isambert, A. Commercial applications of microalgae. J. Biosci. Bioeng. 2006, 101, 87-96.

2. Scott, S.A.; Davey, M.P.; Dennis, J.S.; Horst, I.; Howe, C.J.; Lea-Smith, D.J.; Smith, A.G. Biodiesel from algae: Challenges and prospects. Curr. Opin. Biotechnol. 2010, 21, 277-286.

3. Rodolfi, L.; Zittelli, G.C.; Bassi, N.; Padovani, G.; Biondi, N.; Bonini, G.; Tredici, M.R. Microalgae for Oil: Strain Selection, Induction of Lipid Synthesis and Outdoor Mass Cultivation in a Low-Cost Photobioreactor. Biotechnol. Bioeng. 2009, 102, 100-112.

4. Drevon, C.A.; Baksaas, I.; Krokan, H.E. Omega-3 Fatty Acids: Metabolism and Biological Effects; Birkhauser Verlag: Basel, Switzerland, 1993.

5. Vazhappilly, R.; Chen, F. Eicosapentaenoic Acid and Docosahexaenoic Acid Production Potential of Microalgae and Their Heterotrophic Growth. J. Am. Oil Chem. Soc. 1998, 75, 393-397.

6. Agostoni, C.; Marangoni, F.; Giovannini, M.; Riva, E.; Galli, C.M. Long-chain polyunsaturated fatty acids, infant formula, and breastfeeding. Lancet 1998, 352, 1703-1704.

7. Khozin-Goldberg, I.; Iskandarov, U.; Cohen, K. LC-PUFA from photosynthetic microalgae: Occurrence, biosynthesis, and prospects in biotechnology. Appl. Microbiol. Biotechnol. 2011, 91, 905-915.

8. Cao, Y.; Cao, Y.; Zhao, M. Biotechnological production of eicosapentaenoic acid: From a metabolic engineering point of view. Process Biochem. 2012, 47, 1320-1326. 
9. Nomura, S.; Kanazawa, S.; Fukuhara, S. Effects of eicosapentaenoic acid on platelet activation markers and cell adhesion molecules in hyperlipidemic patients with type 2 diabetes mellitus. J. Diabetes Complicat. 2003, 17, 153-159.

10. Ward, O.P.; Singh, A. Omega-3/6 fatty acids: Alternative sources of production. Process Biochem. 2005, 40, 3627-3652.

11. Guil-Guerrero, J.L.; El-Hassan, B.; Fuentes, M.M.R. Eicosapentaenoic and arachidonic acids purification from the red microalga Porphyridium cruentum. Bioseparation 2001, 9, 299-306.

12. Roche, H.M. Unsaturated fatty acids. Proc. Nutr. Soc. 1999, 58, 397-401.

13. Cohen, Z.; Cohen, S. Preparation of eicosapentaenoic acid (EPA) concentrate from Porphyridium cruentum. J. Am. Oil Chem. Soc. 1991, 68, 16-19.

14. Ozogul, Y.; Simsek, A.; Balikci, E.; Kenar, M. The effects of extraction methods on the contents of fatty acids, especially EPA and DHA in marine lipids. Int. J. Food Sci. Nutr. 2012, 63, 326-331.

15. Abomohra, A.E.F.; Wagner, M.; El-Sheekh, M.; Hanelt, D. Lipid and total fatty acid productivity in photoautotrophic fresh water microalgae: Screening studies towards biodiesel production. J. Appl. Phycol. 2013, 25, 931-936.

16. Seto, A.; Wang, H.L.; Hesseltine, C.W. Culture conditions affect eicosapentaenoic acid content of Chlorella minutissima. J. Am. Oil Chem. Soc. 1984, 61, 892-894.

17. Cohen, Z. The production potential of eicosapentaenoic and arachidonic acids by the red algae Porphyridium cruentum. J. Am. Oil Chem. Soc. 1990, 67, 916-920.

18. Nichols, B.W.; Appleby, R.S. The distribution and biosynthesis of arachidonic acid in algae. Phytochemistry 1969, 8, 1907-1915.

19. Yongmanitchai, W.; Ward, O.P. Screening of algae for potential alternative sources of eicosapentaenoic acid. Phytochemistry 1991, 30, 2963-2967.

20. Iwamoto, H.; Sato, S. Production of EPA by freshwater unicellular algae. J. Am. Oil Chem. Soc. 1986, 63, 434-438.

21. Renaud, S.M.; Zhou, H.C.; Parry, D.L.; Thinh, L.V.; Woo, K.C. Effect of temperature on the growth, total lipid content and fatty acid composition of recently isolated tropical microalgae Isochrysis sp., Nitzschia closterium, Nitzschia paleacea, and commercial species Isochrysis sp. (clone T. ISO). J. Appl. Phycol. 1995, 7, 595-602.

22. Stinson, E.E.; Kwoczak, R.; Kurantz, M.J. Effect of Cultural Conditions on Production of Eicosapentaenoic Acid by Pythium irregular. J. Ind. Microbiol. 1991, 8, 171-178.

23. Durmaz, Y.; Monteiro, M.; Bandarra, N.; Gökpinar, Ş.; Işik, O. The effect of low temperature on fatty acid composition and tocopherols of the red microalga, Porphyridium cruentum. J. Appl. Phycol. 2007, 19, 223-227.

24. Thompson, P.A.; Guo, M.; Harrison, P.J.; Whyte, J.N. Effects of variation in temperature. I. On the fatty acid composition of eight species of marine phytoplankton. J. Phycol. 1992, 28, 488-497.

25. Cohen, Z. Porphyridium cruentum. In Chemicals from Microalgae; Taylor \& Francis: London, UK, 1999; pp. 41-56.

26. Brennan, L.; Owende, P. Biofuels from microalgae-A review of technologies for production, processing, and extractions of biofuels and co-products. Renew. Sust. Energy Rev. 2010, 14, 557-577.

27. Sicko-Goad, L.; Simmons, M.S.; Lazinskey, D.; Hall, J. Effect of light cycle on diatom fatty acid composition and quantitative morphology. J. Phycol. 1988, 24, 1-7. 
28. Erwin, J.; Bloch, K. Biosynthesis of unsaturated fatty acids in microorganisms. Science 1964, 143, 1006-1012.

29. Contantopoulos, G.; Bloch, K. Effect of light intensity on the lipid composition of Euglena gracilis. J. Biol. Chem. 1967, 242, 3538-3542.

30. Rezanka, T.; Doucha, J.; Mares, P.; Podojil, M. Effect of cultivation temperature and light intensity on fatty acid production in the red algae Porphyridium cruentum. J. Basic Microbiol. 1987, 27, 275-278.

31. Qin, J.G. Bio-Hydrocarbons from Algae-Impacts of Temperature, Light and Salinity on Algae Growth; Rural Industries Research and Development Corporation Report (RIRDC): Barton, Australia, 2005.

32. Becker, E.W. Measurement of algal growth. In Microalgae Biotechnology and Microbiology; Cambridge University Press: Cambridge, UK, 1994; pp. 56-62.

33. Miyamoto, K. Renewable Biological Systems for Alternative Sustainable Energy Production; Food \& Agriculture Organization (FAO), United Nations: Osaka, Japan, 1997.

34. Roessler, P.G. Environmental control of glycerolipid metabolism in microalgae: Commercial implications and future research directions. J. Phycol. 1990, 26, 393-399.

35. Cohen, Z. Products from microalgae. In Handbook for Microalgal Mass Culture; Richmond, A., Ed.; CRC Press: Boca Raton, FL, USA, 1986; pp. 421-454.

36. Guillard, R.R.L.; Hargraves, P.E. Stichochrysis immobilis is a diatom, not a chrysophyte. Phycologia 1993, 32, 234-236.

37. Bligh, E.G.; Dyer, W.J. A rapid method for total lipid extraction and purification. Can. J. Biochem. Physiol. 1959, 37, 911-917.

38. Abubakar, L.U.; Mutie, A.M.; Kenya, E.U.; Muhoho, A. Characterization of algae oil (oilgae) and its potential as biofuel in Kenya. J. Appl. Phytotechnol. Environ. Sanit. 2012, 1, 147-153.

39. Li, Y.; Horsman, M.; Wang, B.; Wu, N.; Lan, C.Q. Effects of nitrogen sources on cell growth and lipid accumulation of green alga Neochloris oleoabundans. Appl. Microbiol. Biotechnol. 2008, 81, 629-636.

40. Cohen, Z.; Vonshak, A.; Richmond, A. Effect of environmental conditions on fatty acid composition of the red alga Porphyridium cruentum: Correlation to growth rate. J. Phycol. 1988, 24, 328-332.

41. Oh, S.H.; Han, J.G.; Kim, Y.; Ha, J.H.; Kim, S.S.; Jeong, M.H.; Jeong, H.S.; Kim, N.Y.; Cho, J.S.; Yoon, W.B.; et al. Lipid production in Porphyridium cruentum grown under different culture conditions. J. Biosci. Bioeng. 2009, 108, 429-434.

42. Akimoto, M.; Shirai, A.; Ohtaguchi, K.; Koide, K. Carbon dioxide fixation and polyunsaturated fatty acid production by the red alga Porphyridium cruentum. Appl. Biochem. Biotechnol. 1998, 73, 269-278.

43. Cohen, Z.; Norman, H.A.; Heimer, Y.M. Microalgae as a source of omega-3 fatty acids. World Rev. Nutr. Diet. 1995, 77, 1-31.

(C) 2015 by the authors; licensee MDPI, Basel, Switzerland. This article is an open access article distributed under the terms and conditions of the Creative Commons Attribution license (http://creativecommons.org/licenses/by/4.0/). 